\title{
Monitoring of salt content during the dry salting of ham
}

\author{
ANNA VISY* (1), KARINA ILONA HIDAS, JÓZSEF SURÁNYI, \\ GÁBOR JÓNÁS and LÁSZLÓ FRIEDRICH
}

Department of Refrigeration and Livestock Products Technology, Faculty of Food Science, Szent István University, Ménesi út 43-45., 1118 Budapest, Hungary

\section{CONFERENCE FULL PAPER}

Received: August 13, 2020 • Accepted: September 24, 2020

Published online: November 16, 2020

(C) 2020 The Author(s)

\begin{abstract}
Excessive consumption of salt causes many diseases, including high blood pressure and cardiovascular system disease. In most countries, salt intake is above the WHO guideline daily intake. In Hungary, the average salt intake is more than double the recommended value. Based on these, significant changes are needed in food technology and recipes. To avoid excessive salt intake Hungary has joined the European Union's community program for salt reduction.

The aim of this study was to compare the salt content in different areas of Mangalitsa ham during the dry salting, and compare the average salt content with the regulations of the Codex Alimentarius Hungaricus. The ham was dry salted with $10 \%$ by weight of the meat and placed in a controlled atmosphere storage room. The curing took 21 days. The $\mathrm{NaCl}$ uptake was measured with Mohr method. The ham was cut at 3 points Cushion (C), Fore Cushion (FC) and Butt End (BE). The salt content of BE was generally higher than the other two areas (C, FC). The differences can be explained by the difference in the thickness of the pieces of meat and fat. The average salt content of the different areas did not exceed the threshold limit in the Codex Alimentarius Hungaricus. At the beginning of the experiment, the salt content of each meat layer was very different, the absorbed salt was concentrated in the surface layer. Over time, as the ham lost a lot of water and due to the lack of outer salt, a significant increase in salt content began in the meat centrum. By day 80 , the salt content of the meat centrum exceeded the salt content of both the fat and the surface layer.
\end{abstract}

\footnotetext{
*Corresponding author. E-mail: Visy.Anna@phd.uni-szie.hu
} 


\section{KEYWORDS}

$\mathrm{NaCl}$ content, salt reduction, salt diffusion

\section{INTRODUCTION}

Curing is one of the oldest preservation methods. It is based on the migration of sodium chloride $(\mathrm{NaCl})$ to the meat. The traditional curing technology is also widely used by the modern food industry, and currently it is almost the same as the method used centuries ago. The aim of curing is to increase the shelf life, make the right taste and color, and increase digestibility. The $\mathrm{NaCl}$ treatment results in physico-chemical and biochemical changes in meat (Gil et al., 1999). The $\mathrm{NaCl}$ treatment enhances shelf-life, flavor, juiciness and tenderness of the products (Carcel et al., 2007).

Pork meat curing is conducted by immersing of meat tissues in $\mathrm{NaCl}$ brines, which is known as brine curing procedure. It has been used for several countries by small processors for certain pork cuts. Pickle cure usually gives a product a milder flavor than dry curing and requires less labor (Pearson and Gilett, 1996).

Meat is a complex food. The quality of meat depends on several factors. These include the amount and structure of muscle fiber and fat, as well as their distribution (Felfoldi et al., 2013). The migration of $\mathrm{NaCl}$ from the brine to the meat matrix is normally quite slow due to the complex matrix of meat (Siró et al., 2009). Therefore, curing process is often complemented with tumbling and injecting of the meat: a mechanical treatment, which causes cellular disruption of the meat tissue (Bedinghaus et al., 1992; Gou et al., 2003).

The food industry is currently under pressure from the Food Standards Agency (FSA) to deliver reductions in the salt intake of the population through the introduction of lower salt levels in processed foods (Gilbert and Heisler, 2004). High salt intake increases the risk of cardiovascular disease and high blood pressure. The results of the Dietary Approaches to Stop Hypertension study showed a linear relation between salt intake and blood pressure (Appel et al., 1997). Reducing the salt content to a maximum of $6 \mathrm{~g}$ per day would help to reduce these health problems (Swales, 2001).

According to a study of WHO in 2009, 181 of the 187 countries in the world consume more salt than the recommended value of $5 \mathrm{~g}$ per day. Data from 2009 show that salt intake in Hungary was $14.8 \mathrm{~g}$ per day for adults (Fig. 1) (Trieu et al., 2015).

Based on these data, Hungary has also joined the European Union's community program for salt reduction. The aim of the program is to shape a substantial part of the product range in all EU member states in a compatible way. The focus in Hungary is to reduce the salt content of the food groups most consumed by the Hungarian population by $16 \%$ in the coming years (Martos, 2010). The salt content of cured hams must be reduced from 7.5 to $5 \%(\mathrm{~m} / \mathrm{m})$ in accordance with the regulations (Table 1 ).

\section{MATERIALS AND METHODS}

\section{Materials}

Mangalitsa hams obtained from a local slaughterhouse were used for investigations. Ham was dry salted with $10 \%$ by weight of the meat (the weight of the salt being present on the surface of 


\section{Salt intake per person per day for adults in the WHO European Region from individual country-based surveys, various years}

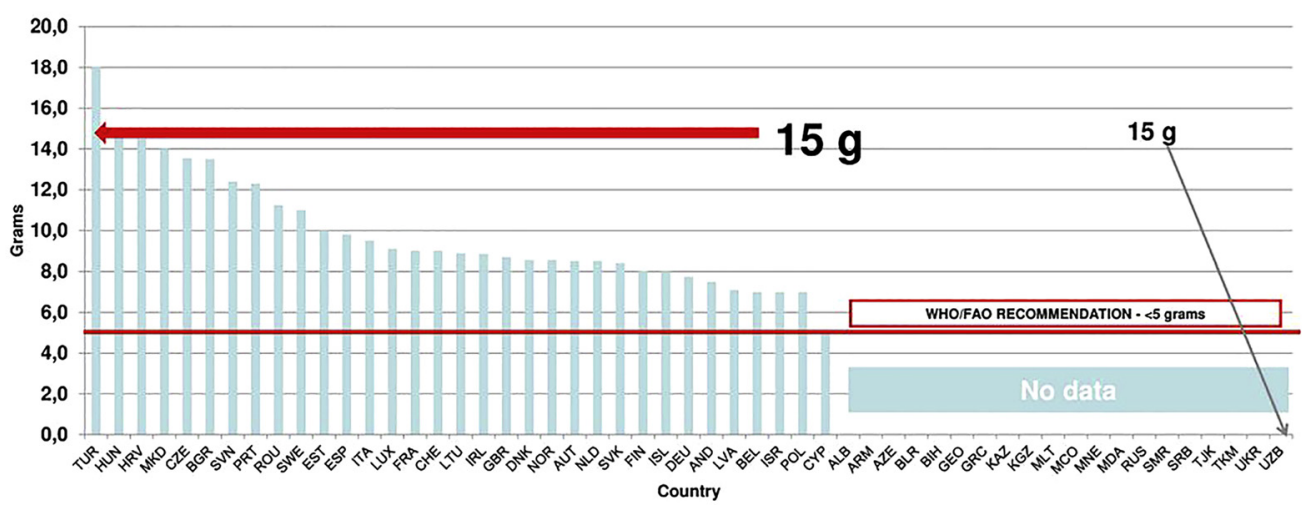

World Health

1.

rasuccincice Europe

Fig. 1. Salt intake (grams) per person per day for adults in the European region from individual countrybased surveys (WHO, 2013)

Table 1. Maximum salt content according to the current Codex Alimentarius Hungaricus for hams (Codex Alimentarius Hungaricus, 2016)

\begin{tabular}{|c|c|c|c|}
\hline Product type & & $\mathrm{NaCl}$ cont & \\
\hline Ham & raw: 5.0 & heat-treated: 3.5 & heat-treated in the form: 2.7 \\
\hline
\end{tabular}

ham was $10 \%$ of the weight of the ham) and placed in a controlled atmosphere storage room. The salting took 21 days. On day 21, the salt was removed from ham and the ham was hanged in the same controlled atmosphere storage room $\left(5^{\circ} \mathrm{C}, 70 \% \mathrm{RH}\right)$. After that the ham was smoked on beech wood at about $40{ }^{\circ} \mathrm{C}$ for $8 \mathrm{~h}$.

During the first 31 days from the beginning of the processing each 3 days the salt content of 4 randomly selected hams was measured. Thereafter, the salt content was measured each 7 days until day 52, then each 14 days until day 80 .

\section{Sampling}

For $\mathrm{NaCl}$ content determination the ham was cut at 3 areas as seen in Fig. 2 (1. Fore Cushion (FC), 2. Cushion (C), and 3. Butt End (BE)). From these areas $5 \times 3 \times 3 \mathrm{~cm}$ cuboid shape samples were cut out and were separated to 3 equal parts (Fig. 3). This sampling was able to determine the $\mathrm{NaCl}$ content on the surface, in the centrum and in the fat part. The fat layer of BE was $14-15 \mathrm{~mm}$, C was 16-17 $\mathrm{mm}$ and FC was $19-21 \mathrm{~mm}$. The meat layer was approximately $80 \mathrm{~mm}$. 


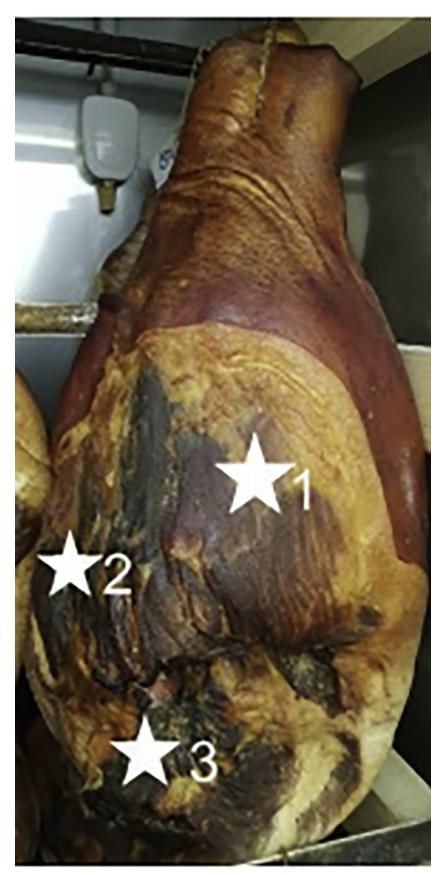

Fig. 2. Test holes on the ham

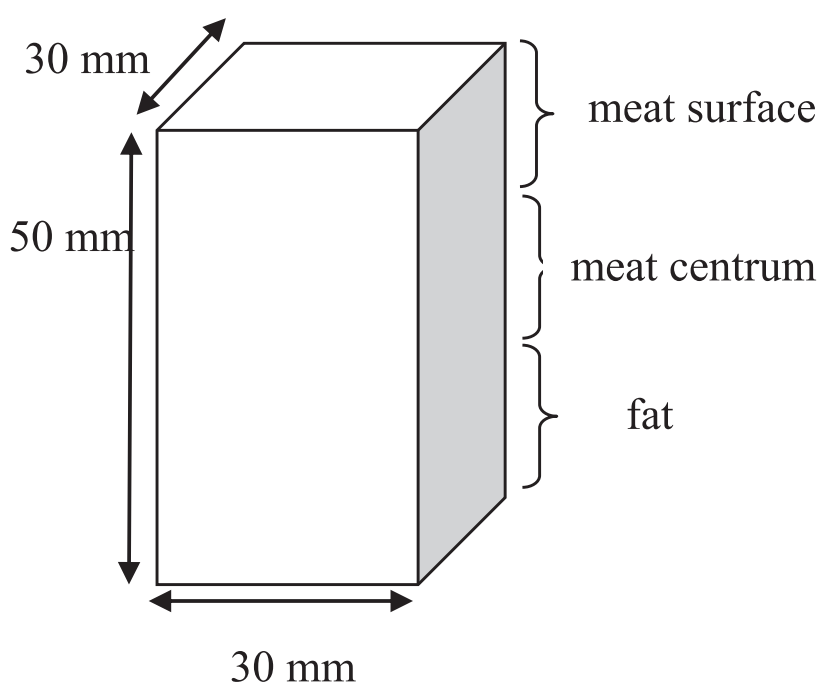

Fig. 3. Sampling of the ham 


\section{$\mathrm{NaCl}$ content determination}

The determination of the amount of $\mathrm{NaCl}$ that penetrated the meat was carried by Mohr method (there were no other additives which contain chlorine) as described by Volpato et al. (2007). The following formula was used to calculate the amount of salt:

$$
\mathrm{NaCl} \text { content }(\%)=\frac{V^{*} N^{*} F^{*} 0.0585 * 100}{m}
$$

$V$ : Consumption of $0.1 \mathrm{~N} \mathrm{AgNO}_{3}$ in titration (mL)

$\mathrm{N}$ : Normality of $\mathrm{AgNO}_{3}$

$F$ : Factor of $0.1 \mathrm{~N} \mathrm{AgNO}_{3}$

$m$ : mass of sample $(\mathrm{g})$

The arithmetic average salt content of all 3 areas was calculated (the average salt content measured on the surface, in the centrum and in the fat was calculated).

\section{Statistical analysis}

Numerical results of $\mathrm{NaCl}$ content were analyzed using IBM SPSS 23.0 software. Statistical analysis was performed by variance analysis (ANOVA). The investigated factors were time, meat layer (surface, centrum, fat) and test holes (FC, C, BE). Differences were considered significant at the $P<$ 0.05 level. Homogeneity of measured values was checked by Levene's test $(P<0.05)$ and the significant differences amongst brining methods were analyzed by Tukey HSD probe $(P<0.05)$.

\section{RESULTS}

Based on the measurements it can be concluded that the increase in the salt content was significant mainly during the first stage of the experiment, during the salting. Fig. 4 shows that the salt content on the surface was typically the highest on the BE. The FC and C had approximately the same salt content. Significant changes were found between the salt content in C and BE. On the 14th day of the experiment, the salt content on the surface of each sampling point reached the permitted (Codex Alimentarius Hungaricus) 5.00\%. Some other studies have shown similar

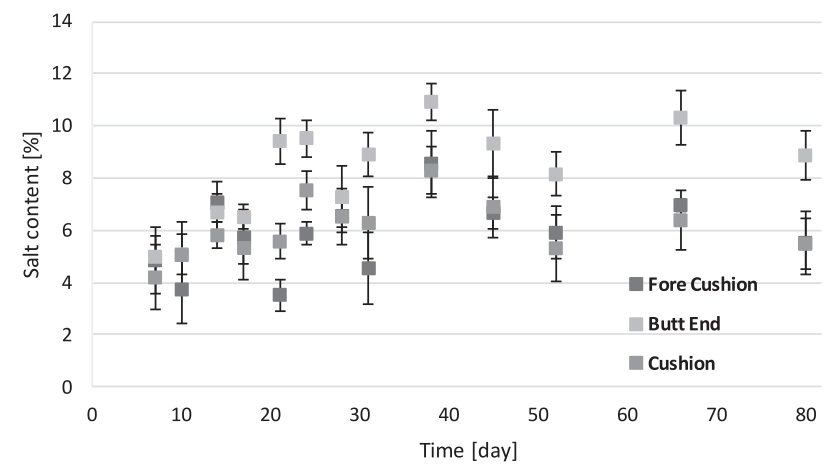

Fig. 4. Change in salt content of meat surface 
results. In a previous study the composition of a number of processed pork products in Ireland was determined. Cured meat products had the highest levels of salt above the FSA proposed targets (Desmond, 1992).

The salt content in the centrum is shown in Fig. 5. It was in this layer that the increase of the salt content was most appreciable. The salt content showed only a slight increase up to day 21, but after that it was higher. Between days 31 and 45, salt content increased in the centrum by an average of $2.08 \%$. The salt content of the $\mathrm{BE}$ in the centrum also exceeded that of the other two studied areas. In this layer the salt content exceeded the limit of $5.00 \%$ by weight at the end of the experiment. The diffusion of salts was quite slow. The connective tissue membranes and cell membrane prevented the free movement of ions in muscular tissue (Ockerman et al., 1999; Vestergaard et al., 2004). The diffusion of $\mathrm{NaCl}$ from brine into meat tissue is a complex process which cannot be described precisely as a simple unsteady unidirectional diffusion with constant diffusion coefficient, due to the meat physical properties changing during brining and/or curing process. For example, increasing $\mathrm{NaCl}$ concentration resulted in enlarged

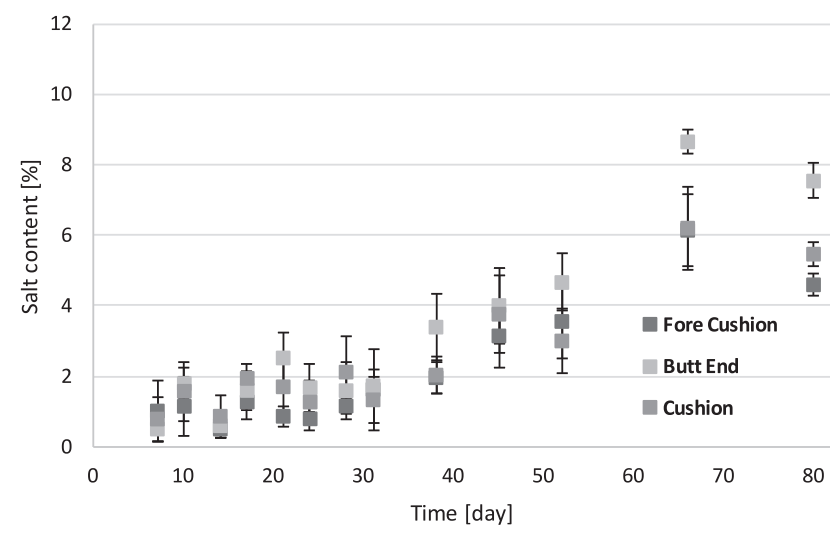

Fig. 5. Change in salt content of meat centrum

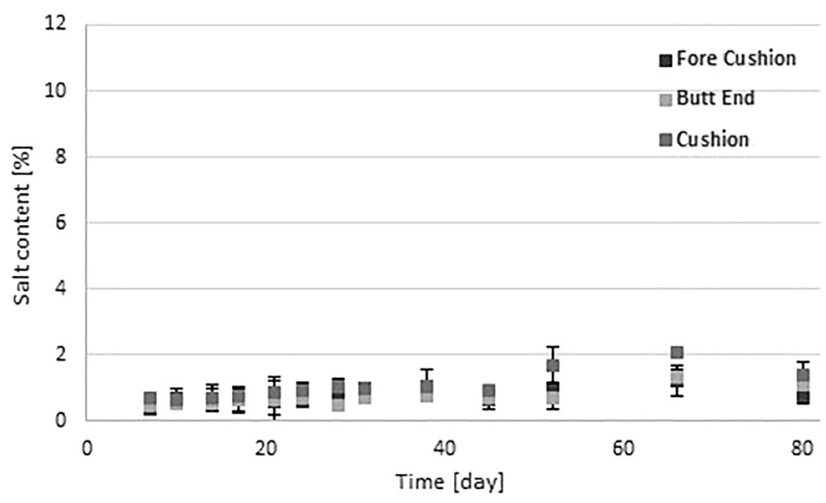

Fig. 6. Change in salt content of fat 


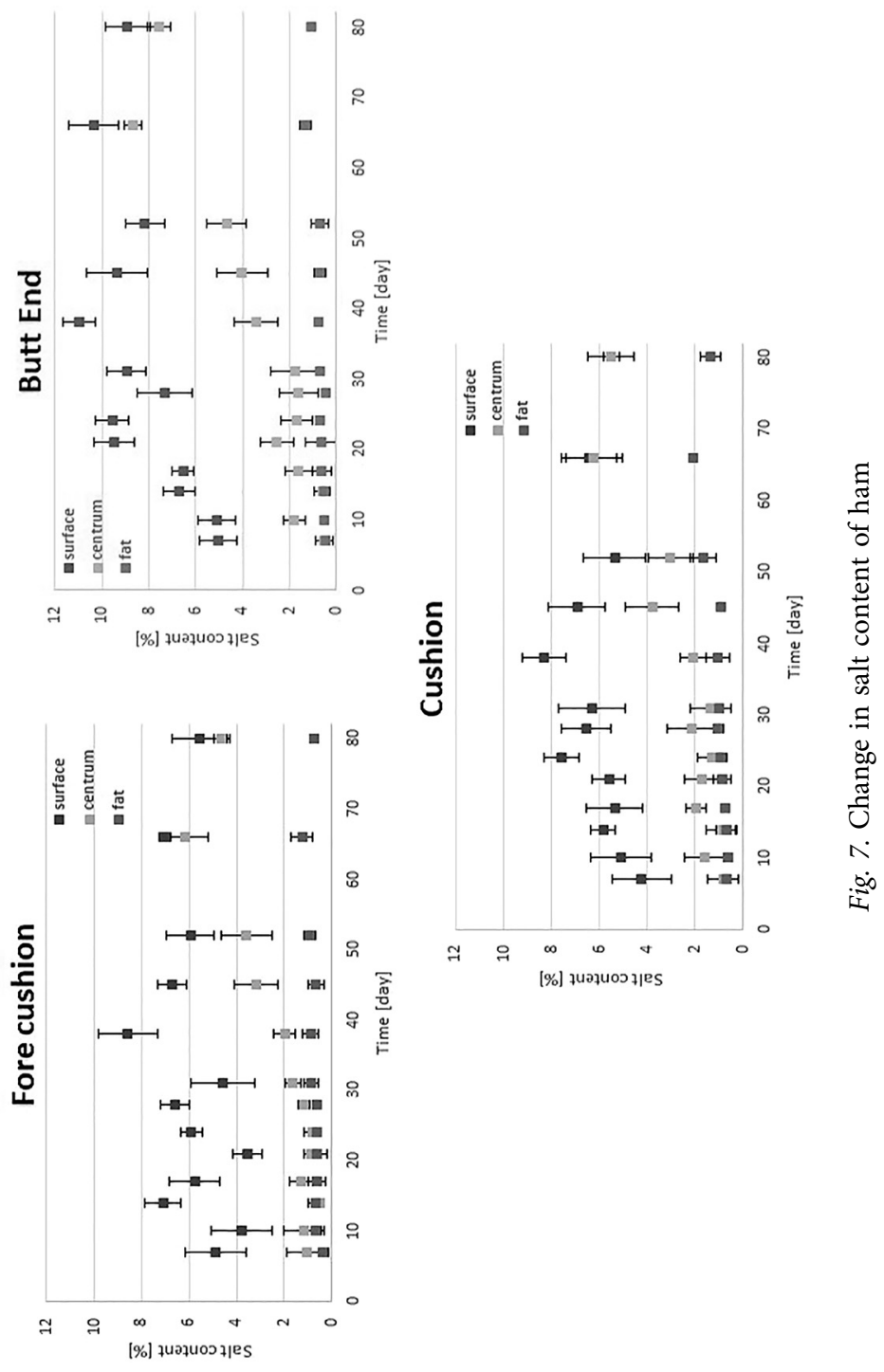


electrostatic repulsion between myofibrils, which then swelled laterally and it also resulted in osmotic dehydration (Vestergaard et al., 2007). Protein denaturation or diffusion of other components may also influence the $\mathrm{NaCl}$ diffusion in tissue (Vestergaard et al., 2005).

In the case of fat layers, the change in salinity is not so remarkable than in the surface and in the core. Fig. 6 showed that in the first two parts of the experiment, the increase of salt content in the fat is minimal. However, during the aging process after smoking, the salt content increased to a greater extent. This is especially noticeable in the case of the C. However, there was no significant difference among areas of FC, $\mathrm{C}$ and $\mathrm{BE}$ in the salt content of this layer. Some researches have shown that fat content affects the perceived salt content (Ruusunen et al., 2001). When $\mathrm{NaCl}$ level increases, it is more remarkable in fatty products (Matulis et al., 1994).

Fig. 7 shows the change in the salt content of all sampling points and layers. The salinity was the highest for all samples at day 66. In the case of a FC, the absorption of salt is most variable, since the differences in salinity between the surface and inner layers fluctuate. However, by the end of the experiment, the salt content in the meat layers was almost equalized. The initial difference of about $3.80 \%$ by weight between the surface and the centrum was below $1 \%$ by day 80. Nevertheless, in the case of bacon layers, the opposite is true.

The average salt content of the meat layers of the hams on day 80 was $5.24 \%$. However, when examined together with the fat layers, the average salt content of the FC was $3.66 \%$, which is a significant difference. During the salting process, the hams still have a high moisture content, so diffusion occurs mainly in the surface layer. During aging, the humidity of the surface layer is significantly reduced by moving air, so that the salt migrates to the inner layers and the moisture to the surface. Because salt is a non-fat soluble compound, the bacon layers have a lower salt content and a significantly slower diffusion. It can be stated that the thickness of the meat and fat layers plays an extremely important role in the formation of the salinity of each ham part. The thicker the layer of meat, the more moisture the area holds, allowing it to absorb more salt and to absorb it more quickly.

On day 80 , the average salt content of the FC was $3.66 \%$, the average salt content of BE was $5.99 \%$ and that of the $\mathrm{C}$ was $4.48 \%$. Based on the measured data, the average salt content of the whole ham can be inferred, which is $4.71 \%$. Thus, the salt content of the examined ham is below the threshold limit of $5.00 \%$ of the Codex Alimentarius Hungaricus. On the basis of decree 48/ 2016, III/18. of Codex Alimentarius Hungaricus a cured product can be considered salt matured if the average salt, nitrite and nitrate content measured in the cross section of the product is within the limits prescribed by law (Codex Alimentarius Hungaricus).

\section{CONCLUSION}

Our results provided the information about the salt diffusion into the Mangalitsa ham during 80 days of brining and aging process. There were differences in salt diffusion between the different areas of the ham due to thickness of the layers of meat and fat. The salt content of BE was higher than that of FC and $\mathrm{C}$ because the fat layer of BE was thinner. At the beginning of the experiment, the salinity of each layer of meat was very different, absorbed salt was concentrated on the surface. During aging, significant increase in salt content began in the centrum. By the end of the experiment the salinity of the examined meat layers was almost completely equalized. 
Our results indicated that the application of dry curing and aging technology on ham can be applied in accordance with the salt content requirement of Codex Alimentarius Hungaricus.

\section{ACKNOWLEDGEMENT}

The Project is supported by the SZIE Doctoral School of Food Sciences and European Union and co-financed by the European Social Fund (grant agreement no. EFOP-3.6.3-VEKOP-162017-00005).

\section{REFERENCES}

Appel, L.J., Moore, T.J., Obarzanek, E., Vollmer, W.M., Svetkey, L.P., Sacks, F.M., (1997). A clinical trial of the effects of dietary patterns on blood pressure. DASH Collaborative Research Group 1997. New England Journal of Medicine, 336: 1117-1124.

Bedinghaus, A.J., Ockerman, H.W., Parrett, N.A., and Plimpton, R.F. (1992). Intermittent tumbling affects quality and yield in prerigor sectioned and formed ham. Journal of Food Science, 57: 1063-1065.

Cárcel, J.A., Benedito, J., Bon, J., and Mulet, A. (2007). High intensity ultrasound effects on meat brining. Meat Science, 76: 611-619.

Codex Alimentarius Hungaricus. (2016). Regulation No.1-3/13-1 on meat products and prepared meat, pp. 7-14.

Desmond, E.M. (1992). Compositional analysis of cured pig meat products in Ireland. Teagasc, The National Food Centre. Internal report.

Felfoldi, J., Baranyai, L., Firtha, F., Friedrich, L., and Balla, Cs. (2013). Image processing based method for characterization of the fat/meat ratio and fat distribution of pork and beef samples. Progress in Agricultural Engineering Sciences, 9: 27-53.

Gil, M., Guerrero, L., and Sárraga, C. (1999). The effect of meat quality, salt and ageing time on biochemical parameters of dry-cured Longissimus dorsi muscle. Meat Science, 51: 329-337.

Gilbert, P.A. and Heisler, G. (2004). Salt and health. Nutrition Bulletin, 30: 62-69.

Gou, P., Comaposada, J. and Arnau, J. (2003). NaCl content and temperature effects on moisture diffusivity in the Gluteus medius muscle of pork ham. Meat Science, 63(1), 29-34. doi: https://doi.org/10.1016/ s0309-1740(02)00048-7. In press.

Martos, É. (2010). Európai összefogás a lakosság sóbevitelének csökkentése érdekében - Nemzeti sócsökkentő program. Metabolizmus, 8: 23-24.

Matulis, R.D., McKeith, F.K., and Brewer, M.S. (1994). Physical and sensory characteristics of commercially available frankfurters. Journal of Food Quality, 17: 263-271.

Ockerman, H.W., Crespo, L.F., Solvedilla, G.H., Fernandez, A.P., Gonzalez, N.C., Zubeldia, B.B., (1999). Diffusion coefficient of salt during meat salting in the production of Jamo'n. Ohio State Bulletin Special Circular, 172-199.

Pearson, A.M. and Gillett, T.A. (1996). In processed meats, 3rd ed. Ch 11, pp. 291-310. Chapman and Hall, New York, NY.

Ruusunen, M., Särkkä-Tirkkonen, M., and Puolanne, E. (2001). Saltiness of coarsely ground cooked ham with reduced salt content. Agricultural and Food Science in Finland, 10: 27-32. 
Siró, I., Vén, C., Balla, C., Jónás, G., Zeke, I., and Friedrich, L. (2009). Application of an ultrasonic assisted curing technique for improving the diffusion of sodium chloride in porcine meat. Journal of Food Engineering, 91(2): 353-362.

Swales, J. (2001). Salt, blood pressure and health. Nutrition Bulletin, 26: 133-139.

Trieu K., Neal, B., Hawkes, C., Dunford, E., Campbell, N., and Rodriguez-Fernandez, R. (2015). Salt reduction initiatives around the world - a systematic review of progress towards the global target. PLoS One, 10(7): e0130247.

Vestergaard, C., Andersen, B.L, and Adler-Nissen, J. (2007). Sodium diffusion in cured pork determined by 22Na radiology. Meat Science, 76(2): 258-265.

Vestergaard, C., Risum, J., and Adler-Nissen, J. (2004). Quantification of salt concentrations in cured pork by computed tomography. Meat Science, 68: 101-113.

Vestergaard, C., Risum, J., and Adler-Nissen, J. (2005). 23Na-MRI quantification of sodium and water mobility in pork during brine curing. Meat Science, 69(4): 663-672.

Volpato, G., Michielin, E.M.Z., Ferreira, S.R.S., and Petrus, J.C.C. (2007). Kinetics of the diffusion of sodium chloride in chicken breast (Pectoralis major) during curing. Journal of Food Engineering, 79(3): 779-785.

WHO. (2013). Mapping salt reduction initiatives in the WHO European Region. WHO Regional Office for Europe.

Open Access. This is an open-access article distributed under the terms of the Creative Commons Attribution 4.0 International License (https://creativecommons.org/licenses/by/4.0/), which permits unrestricted use, distribution, and reproduction in any medium, provided the original author and source are credited, a link to the CC License is provided, and changes - if any - are indicated. (SID_1) 